鉱物学雑誌 第 15 巻 第 6 号 $331 \sim 341 \quad 1982$ 年 11 月
鉱
物
学
雑
誌

第 15 巻 第6 号 1982 年 11 月

$\mathrm{Sr}_{2} \mathrm{Zn} \mathrm{Ge}_{2} \mathrm{O}_{7}$ の結晶構造

越 智 康 雄*

田 中 清 明*

森川日出貴*

丸茂 文 幸*

The Crystal Structure of $\mathrm{Sr}_{2} \mathrm{ZnGe}_{2} \mathrm{O}_{7}$

Yasuo OCHI*, Kiyoaki TANAKA*, Hideki

MORIKAWA* and Fumiyuki MARUMO

\begin{abstract}
The crystal structure of $\mathrm{Sr}_{2} \mathrm{ZnGe}_{2} \mathrm{O}_{7}$ was refined to $\mathrm{R}=0.023$ with three-dimensional diffraction data. The crystal is isomorphous with melilite, having cell dimensions $a=8.169(1)$ and $c=5.337(1) \AA$. The average tetrahedral $\mathrm{Zn}-\mathrm{O}$ and $\mathrm{Ge}-\mathrm{O}$ distances were 1.953 and $1.748 \AA$, respectively. $\mathrm{Zn}$ and $\mathrm{Ge}$ atoms showed complete ordering.

1983 年 4 月 4 日受理

* 東京工業大学工業材料研究所

Research Laboratory of Engineering Materials, Tokyo Institute of Technology, Nagatsuta 4259, Midori-ku, Yokohama, 227
\end{abstract}


1.はじめに

天然の melilite は gehlenite $\left(\mathrm{Ca}_{2} \mathrm{Al}_{2} \mathrm{SiO}_{7}\right)$ と åkermanite $\left(\mathrm{Ca}_{2} \mathrm{MgSi}_{2} \mathrm{O}_{7}\right)$ を 端成分とする固溶体に若千の $\mathrm{Fe}$ イオン, $\mathrm{Na}$ イオンを含んでいる。この構 造は他のイオンで置換され易く, 一般式を $\mathrm{X}_{2} \mathrm{~T}_{3} \mathrm{O}_{7}$ と表わすと,

$\mathrm{X}: \mathrm{Na}^{+}, \mathrm{Ba}^{2+}, \mathrm{Ca}^{2+}, \mathrm{Pb}^{2+}, \mathrm{Sr}^{2+}, \mathrm{Ln}^{3+}, \mathrm{Y}^{3+}$

$\mathrm{T}: \mathrm{Be}^{2+}, \mathrm{Cd}^{2+}, \mathrm{Co}^{2+}, \mathrm{Cu}^{2+}, \mathrm{Fe}^{2+}, \mathrm{Mg}^{2+}, \mathrm{Mn}^{2+}, \mathrm{Zn}^{2+}, \mathrm{Al}^{8+}, \mathrm{B}^{3+}, \mathrm{Fe}^{3+}$, $\mathrm{Ga}^{3+}, \mathrm{Ge}^{4+}, \mathrm{Si}^{4+}$

のイオンの組み合せから成る化合物が報告 ${ }^{12)}$ されている。ここで, $\mathrm{X}$ は 8 配位席，Tは 4 配位席の陽イオンを表わし, Ln は希土類元素である。単結 晶構造解析は melilite ${ }^{3)}, \mathrm{Y}_{2} \mathrm{Si} \mathrm{Be}_{2} \mathrm{O}_{7}{ }^{4)}$, hardystonite $\left(\mathrm{Ca}_{2} \mathrm{ZnSi}_{2} \mathrm{O}_{7}\right)^{5)}$, soda melilite $\left(\mathrm{CaNaAlSi}_{2} \mathrm{O}_{7}\right)^{6)}$, gehlenite ${ }^{7)}$, àkermanite ${ }^{8)}$, gugiaite $\left(\mathrm{Ca}_{2} \mathrm{BeSi}_{2} \mathrm{O}_{7}\right)^{9)}$ について報告されており，大部分が Xとして $\mathrm{Ca}^{2+}$ イオンを含む化合物であ る。これらの他に粉末 X 線回折図形を用いた Rietveld 法(0)による構造解析 の結果が $\mathrm{Ln}_{2} \mathrm{GeBe}_{2} \mathrm{O}_{7}$ について越智ら ${ }^{11)} に よ り$ 報告されている。

メリライト型構造は正方晶系の空間群 $\mathrm{P} 42_{1} \mathrm{~m}$ に属し, $\mathrm{TO}_{4}$ 四面体の 5 員環からなる層を層間の Xイオンが結び付けることにより構造が形成され ている。T イオンには $2(\mathrm{a})$ 位置を占める $\mathrm{T}(1)$ と 4 (e) 位置を占める $\mathrm{T}(2)$

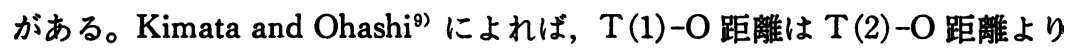
長く, $\mathrm{T}(1) \mathrm{O}_{4}$ 四面体は $\mathrm{T}(2) \mathrm{O}_{4}$ 四面体より歪が小さい。

本研究は層間に $\mathrm{Sr}^{2+}$ イオンを含む $\mathrm{Sr}_{2} \mathrm{ZnGe}_{2} \mathrm{O}_{7}$ の単結晶を合成して結晶 構造を解析し, 層間に $\mathrm{Ca}^{2+}$ イオンを含むメリライト型結晶の構造と比較し, その構造上の特徴を明らかにすることを目的としている。

\section{2. 実臨}

和光純薬(株) 製の特級試薬 $\mathrm{GeO}_{2} . \mathrm{ZnO}, \mathrm{SrCO}_{3}$ を $\mathrm{Sr}_{2} \mathrm{ZnGe}_{2} \mathrm{O}_{7}$ 組成に調合 し, 白金ルツボに入れ, $\mathrm{SiC}$ 発熱体電気炉を用いて $1500{ }^{\circ} \mathrm{C} て ゙$ 熔融し, 1 時 間保持後毎時 $20^{\circ} \mathrm{C}$ の降温速度で冷却し, 単結晶を合成した。粉末 $\mathrm{X}$ 線回折 図形にはメリライト型化合物 1 相のみが確認された。柱状または板状の, 無 色透明な単結晶が得られ，大きい結晶は数 $\mathrm{mm}$ まで成長していた。DTA で 測定した融点は $1450^{\circ} \mathrm{C}$ であった。

Bond $^{12)}$ 法を用いて単結晶を直径 $0.21 \mathrm{~mm}$ の球に整形し, 理学電機社製 4 軸型回折計 AFC-5 UD を用いて強度データを収集した。グラファイトモノ 
越智康雄・田中清明・森川日出貴 - 丸茂文幸

Table 1. Observed structure amplitudes of $\mathrm{Sr}_{2} \mathrm{ZnGe}_{2} \mathrm{O}_{7}$

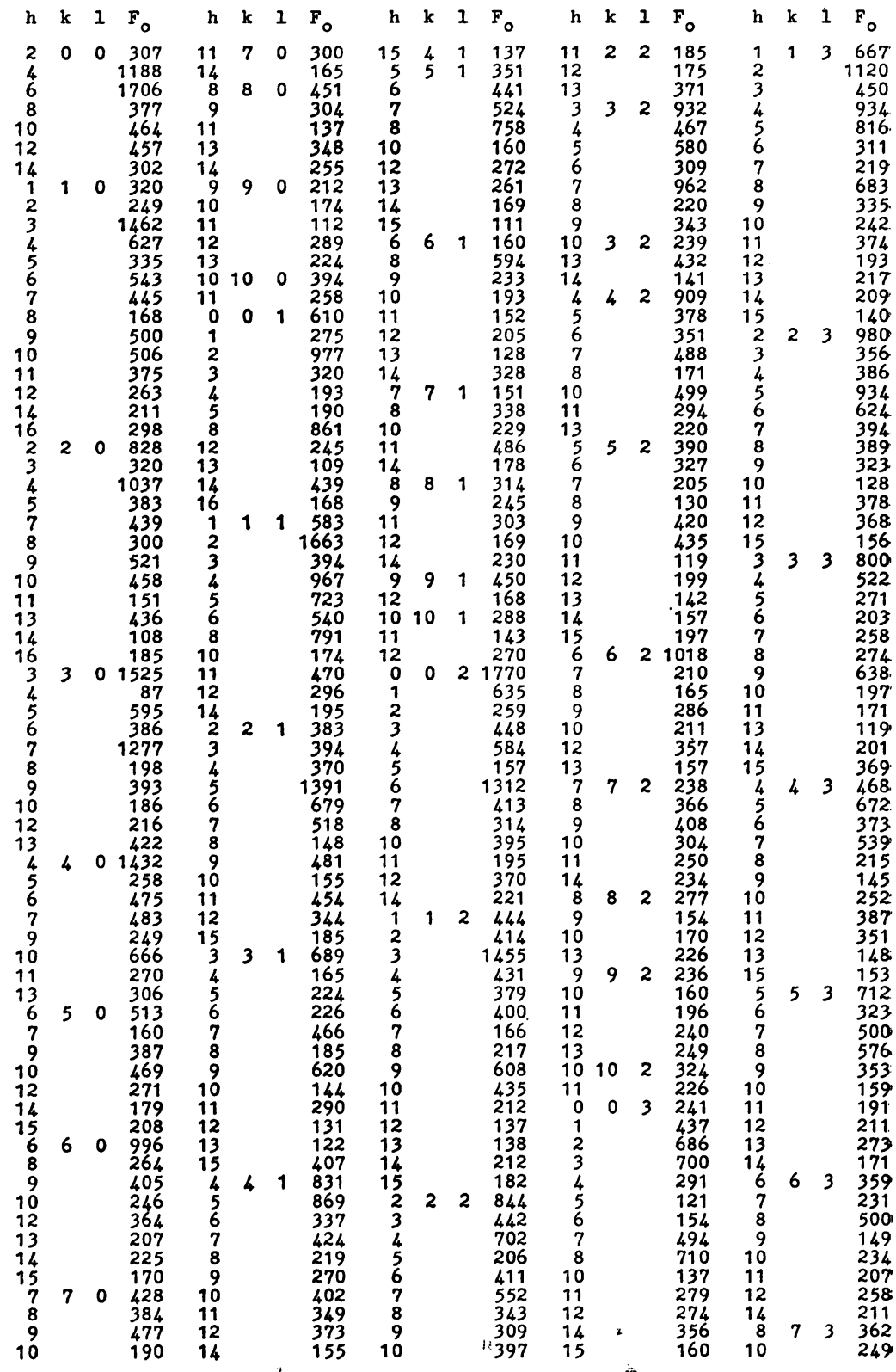


Table 1. (Continued)

\begin{tabular}{|c|c|c|c|c|c|c|c|c|c|c|c|c|c|c|c|c|c|c|c|}
\hline h & k & 1 & $F_{0}$ & $\mathrm{~h}$ & k & 1 & $F_{0}$ & $\mathrm{~h}$ & k & 1 & $F_{0}$ & $\mathrm{~h}$ & k & 1 & $F_{0}$ & $\mathrm{~h}$ & k & 1 & $F_{0}$ \\
\hline 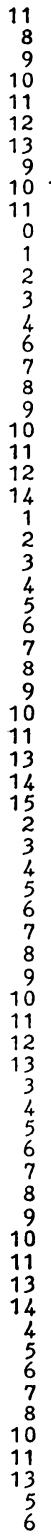 & $\begin{array}{r}9 \\
10\end{array}$ & $\begin{array}{l}3 \\
3 \\
4\end{array}$ & $\begin{array}{l}424 \\
265 \\
146 \\
151 \\
277 \\
231 \\
135 \\
476 \\
202 \\
214 \\
1613 \\
377 \\
159 \\
829 \\
415 \\
973 \\
505 \\
97 \\
206 \\
188 \\
244 \\
360 \\
124 \\
206 \\
304 \\
871 \\
613 \\
382 \\
174 \\
144 \\
306 \\
500 \\
391 \\
177 \\
206 \\
220 \\
169 \\
753 \\
154 \\
552 \\
195 \\
305 \\
394 \\
325 \\
158 \\
327 \\
219 \\
193 \\
247 \\
662 \\
484 \\
523 \\
353 \\
710 \\
197 \\
289 \\
262 \\
145 \\
296 \\
177 \\
646 \\
323 \\
269 \\
561 \\
193 \\
352 \\
295 \\
244 \\
385 \\
171\end{array}$ & $\begin{array}{r}8 \\
9 \\
10 \\
13 \\
14 \\
6 \\
7 \\
8 \\
9 \\
10 \\
11 \\
12 \\
13 \\
13 \\
8 \\
9 \\
10 \\
11\end{array}$ & $\begin{array}{r}9 \\
10 \\
0\end{array}$ & 5 & $\begin{array}{l}249 \\
419 \\
291 \\
168 \\
175 \\
720 \\
274 \\
193 \\
177 \\
142 \\
197 \\
346 \\
127 \\
306 \\
355 \\
307 \\
153 \\
262 \\
187 \\
212 \\
164 \\
246 \\
178 \\
203 \\
228 \\
231 \\
260 \\
597 \\
371 \\
544 \\
192 \\
273 \\
318 \\
295 \\
356 \\
273 \\
118 \\
145 \\
676 \\
529 \\
260 \\
424 \\
561 \\
135 \\
279 \\
310 \\
271 \\
275 \\
257 \\
177 \\
180 \\
633 \\
306 \\
462 \\
614 \\
412 \\
373 \\
223 \\
328 \\
165 \\
798 \\
308 \\
216 \\
165 \\
249 \\
485 \\
169 \\
123 \\
171 \\
223\end{array}$ & $\begin{array}{r}5 \\
6 \\
7 \\
8 \\
11 \\
12 \\
5 \\
3 \\
7 \\
7 \\
8\end{array}$ & $\begin{array}{l}9 \\
0\end{array}$ & $\begin{array}{l}5 \\
5 \\
6\end{array}$ & $\begin{array}{l}394 \\
452 \\
407 \\
182 \\
276 \\
229 \\
506 \\
117 \\
240 \\
275 \\
300 \\
248 \\
182 \\
216 \\
352 \\
132 \\
364 \\
284 \\
141 \\
201 \\
204 \\
295 \\
279 \\
161 \\
272 \\
214 \\
387 \\
656 \\
479 \\
550 \\
160 \\
546 \\
443 \\
255 \\
337 \\
201 \\
326 \\
545 \\
290 \\
251 \\
168 \\
226 \\
391 \\
443 \\
522\end{array}$ & 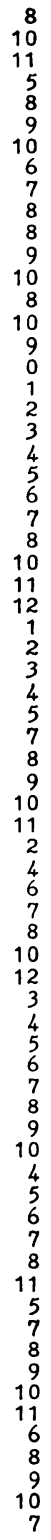 & $\begin{array}{l}9 \\
0\end{array}$ & $\begin{array}{l}6 \\
7\end{array}$ & $\begin{array}{l}322 \\
165 \\
302 \\
295 \\
286 \\
365 \\
153 \\
502 \\
227 \\
158 \\
305 \\
209 \\
278 \\
162 \\
248 \\
281 \\
527 \\
224 \\
415 \\
190 \\
523 \\
137 \\
299 \\
258 \\
234 \\
304 \\
192 \\
125 \\
479 \\
189 \\
183 \\
322 \\
404 \\
293 \\
221 \\
188 \\
206 \\
132 \\
468 \\
217 \\
399 \\
187 \\
288 \\
123 \\
274 \\
675 \\
234 \\
165 \\
126 \\
180 \\
183 \\
387 \\
173 \\
184 \\
234 \\
385 \\
291 \\
186 \\
227 \\
416 \\
210 \\
145 \\
230 \\
183 \\
163 \\
251 \\
211 \\
114 \\
272 \\
241\end{array}$ & 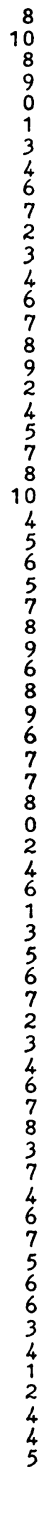 & $\begin{array}{l}5 \\
6 \\
0 \\
1\end{array}$ & $\begin{array}{r}9 \\
9 \\
10\end{array}$ & $\begin{array}{l}248 \\
165 \\
175 \\
121 \\
175 \\
173 \\
307 \\
168 \\
246 \\
232 \\
459 \\
217 \\
307 \\
163 \\
189 \\
280 \\
212 \\
230 \\
138 \\
438 \\
235 \\
152 \\
154 \\
230 \\
293 \\
170 \\
297 \\
228 \\
229 \\
150 \\
143 \\
285 \\
211 \\
288 \\
158 \\
212 \\
141 \\
445 \\
288 \\
463 \\
296 \\
342 \\
199 \\
208 \\
151 \\
292 \\
228 \\
161 \\
135 \\
249 \\
184 \\
136 \\
594 \\
224 \\
179 \\
302 \\
155 \\
208 \\
196 \\
232 \\
147 \\
181 \\
175 \\
321 \\
277 \\
112 \\
330\end{array}$ \\
\hline
\end{tabular}


クロメータで単色化した MoK $\alpha$ 線を使用し, 弱い反射は 4 回くり返して測 定し， $2 \theta=90^{\circ}$ までの範囲で $|\mathrm{F}|>5 \sigma(|\mathrm{F}|)$ を満足する 697 個の独立な反射デ 一タを得た。得られたデータに吸収と L p 因子の補正を行ない, 実測構造因 子の初期值 (Table 1) を得た。格子定数は 4 軸型回折計を用いて測定した $73^{\circ}<2 \theta<78^{\circ}$ の範囲内の 35 個の $2 \theta$ 角を利用し, $\lambda=0.71069 \AA$ とし, $\mathrm{a}=$ 8. $169(1), c=5.337$ (1) $\AA$ を得た。なお, JCPDS 12-346に記載の值は $a=$ 8. $13, c=5.27 \AA$ である。

\section{3. 構造の精密化}

$\mathrm{Ca}_{2} \mathrm{ZnSi}_{2} \mathrm{O}_{7}$ の パラメータ $\mathrm{T}^{13)}$ を用いて精密化を行った。中性の原子散乱因子 ${ }^{14)}$ を用い, 異常分散 ${ }^{14)}$ を 考慮した。非等方性温度因子を用い，等方性の消衰効果補正を施した結果， R因子は 0.023 に収束した。得られた位置パラメータをTable 2 に, 温度因 子を Table 3 に示す。また，プログラム RSDA-4 ${ }^{15)}$ によって計算した原子

Table 2 Final atomic coordinates and their standard deviations in parentheses.

\begin{tabular}{lcllc}
\hline Atom & Position & \multicolumn{1}{c}{$\mathrm{x}$} & \multicolumn{1}{c}{$\mathrm{y}$} & \multicolumn{1}{c}{$\mathrm{z}$} \\
$\mathrm{Sr}$ & $4(\mathrm{e})$ & $.33482(5)$ & $1 / 2-\mathrm{x}$ & $.50656(12)$ \\
$\mathrm{Zn}$ & $2(\mathrm{a})$ & 0 & 0 & 0 \\
$\mathrm{Ge}$ & $4(\mathrm{e})$ & $.14245(6)$ & $1 / 2-\mathrm{x}$ & $-.04745(11)$ \\
$\mathrm{O}(1)$ & $2(\mathrm{c})$ & $1 / 2$ & 0 & $.17652(130)$ \\
$\mathrm{O}(2)$ & $4(\mathrm{e})$ & $.13891(44)$ & $1 / 2-\mathrm{x}$ & $.27401(73)$ \\
$\mathrm{O}(3)$ & $8(\mathrm{f})$ & $.08236(49)$ & $.18014(44)$ & $-.20486(60)$ \\
\hline
\end{tabular}

Table 3 Anisotropic thermal parameters $\left(\times 10^{4}\right)$ and their standard deviations in parentheses.

\begin{tabular}{lcccccc}
\hline Atom & $\mathrm{U}_{11}$ & $\mathrm{U}_{22}$ & $\mathrm{U}_{33}$ & $\mathrm{U}_{12}$ & $\mathrm{U}_{13}$ & $\mathrm{U}_{23}$ \\
$\mathrm{Sr}$ & $117(1)$ & $\mathrm{U}_{11}$ & $91(2)$ & $40(2)$ & $5(1)$ & $-\mathrm{U}_{13}$ \\
$\mathrm{Zn}$ & $77(2)$ & $\mathrm{U}_{11}$ & $101(3)$ & 0 & 0 & 0 \\
$\mathrm{Ge}$ & $71(1)$ & $\mathrm{U}_{11}$ & $59(2)$ & $3(2)$ & $1(1)$ & $-\mathrm{U}_{13}$ \\
$\mathrm{O}(1)$ & $167(18)$ & $\mathrm{U}_{11}$ & $89(22)$ & $-79(25)$ & 0 & 0 \\
$\mathrm{O}(2)$ & $153(11)$ & $\mathrm{U}_{11}$ & $59(13)$ & $49(17)$ & $-4(9)$ & $-\mathrm{U}_{13}$ \\
$\mathrm{O}(3)$ & $240(17)$ & $94(11)$ & $99(11)$ & $-62(11)$ & $31(11)$ & $-19(10)$ \\
\hline
\end{tabular}


Table 4 Bond lengths $(\AA)$ and angles $\left({ }^{\circ}\right)$ in $\mathrm{Sr}_{2} \mathrm{ZnGe}_{2} \mathrm{O}_{7}$.

\begin{tabular}{rrrr}
\hline Symmetry code : None & $\mathrm{x}$, & $\mathrm{y}$, & $\mathrm{z}$ \\
$\mathrm{i}$ & $-\mathrm{x}$, & $-\mathrm{y}$, & $\mathrm{z}$ \\
$\mathrm{ii}$ & $\mathrm{y}$, & $-\mathrm{x}$, & $-\mathrm{z}$ \\
$\mathrm{iii}$ & $1 / 2+\mathrm{x}$, & $1 / 2-\mathrm{y}$, & $-\mathrm{z}$ \\
$\mathrm{iv}$ & $1 / 2-\mathrm{y}$, & $1 / 2-\mathrm{x}$, & $1+\mathrm{z}$ \\
$\mathrm{v}$ & $\mathrm{x}$, & $\mathrm{y}$, & $1+\mathrm{z}$ \\
$\mathrm{vi}$ & $1 / 2-\mathrm{y}$, & $1 / 2-\mathrm{x}$, & $\mathrm{z}$ \\
$\mathrm{vii}$ & $-\mathrm{x}$, & $1-\mathrm{y}$, & $\mathrm{z}$ \\
$\mathrm{viii}$ & $-\mathrm{y}$, & $\mathrm{x}$, & $-\mathrm{z}$ \\
$\mathrm{ix}$ & $1 / 2+\mathrm{x}$, & $1 / 2-\mathrm{y}$, & $1-\mathrm{z}$ \\
$\mathrm{x}$ & $1 / 2-\mathrm{x}$, & $-1 / 2+\mathrm{y}$, & $1-\mathrm{z}$
\end{tabular}

Bond lengths

The $\mathrm{ZnO}_{4}$ tetrahedron

$\begin{array}{llllll}\mathrm{Zn}-\mathrm{O}(3) & (4 \mathrm{x}) & 1.953(4) & \mathrm{O}(3)-\mathrm{Zn}-\mathrm{O}\left(3^{\mathrm{i}}\right) & (2 \mathrm{x}) & 111.9(1) \\ \mathrm{O}(3)-\mathrm{O}\left(3^{\mathrm{i}}\right) & (2 \mathrm{x}) & 3.236(5) & \mathrm{O}(3)-\mathrm{Zn}-\mathrm{O}\left(3^{\mathrm{il}}\right) & (4 \mathrm{x}) & 108.3(2) \\ \mathrm{O}(3)-\mathrm{O}\left(3^{\mathrm{i}}\right) & (4 \mathrm{x}) & 3.165(5) & & & \end{array}$

The $\mathrm{Ge}_{2} \mathrm{O}_{7}$ group

\begin{tabular}{|c|c|c|c|c|c|}
\hline $\mathrm{Ge}-\mathrm{O}(3)$ & $(2 \mathbf{x})$ & 1. $746(4)$ & $\mathrm{Ge}-\mathrm{O}\left(1^{\nabla i i i}\right)-\mathrm{Ge}^{\nabla}$ & & $134.6(4)$ \\
\hline $\mathrm{Ge} \quad-\mathrm{O}(2)$ & & 1. $716(4)$ & $\mathrm{O}(2)-\mathrm{Ge}-\mathrm{O}\left(1^{\nabla \mathrm{iii}}\right)$ & & 111. $3(2)$ \\
\hline $\mathrm{Ge}-\mathrm{O}\left(1^{\mathrm{vi} i \mathrm{i}}\right)$ & & 1. $784(3)$ & $\mathrm{O}(3)-\mathrm{Ge}-\mathrm{O}\left(1^{\mathrm{viii}}\right)$ & $(2 x)$ & 99. $9(2)$ \\
\hline $\mathrm{O}(2)-\mathrm{O}\left(1^{\mathrm{vi} \mathrm{i} i}\right)$ & & $2.891(7)$ & $\mathrm{O}(3)-\mathrm{Ge}-\mathrm{O}\left(3^{\nabla i}\right)$ & & 103. $6(2)$ \\
\hline$O(3)-O\left(1^{v i i i}\right)$ & $(2 \mathrm{x})$ & 2. $703(4)$ & $\mathrm{O}(2)-\mathrm{Ge}-\mathrm{O}(3)$ & $(2 \mathbf{x})$ & $119.4(2)$ \\
\hline$O(3)-O\left(3^{v i}\right)$ & & $2.744(5)$ & & & \\
\hline $\mathrm{O}(3)-\mathrm{O}(2)$ & $(2 x)$ & $2.988(5)$ & & & \\
\hline
\end{tabular}

The $\mathrm{SrO}_{8}$ polyhedron

$\begin{array}{ll}\mathrm{Sr}-\mathrm{O}\left(3^{\mathrm{i}}\right), \mathrm{O}\left(3^{\mathrm{v}}\right) & 2.577(4) \\ \mathrm{Sr}-\mathrm{O}(2) & 2.581(4) \\ \mathrm{Sr}-\mathrm{O}(1) & 2.597(5) \\ \mathrm{Sr}-\mathrm{O}\left(3^{\mathrm{ii}}\right), \mathrm{O}\left(3^{\mathrm{ii}}\right) & 2.877(4) \\ \mathrm{Sr}-\mathrm{O}\left(2^{\mathrm{i} x}\right), \mathrm{O}\left(2^{\mathrm{x}}\right) & 2.755(4)\end{array}$

間距離と結合角を Table 4 に示す。 


\section{4. 討 論}

層間に $\mathrm{Ca}^{2+}$ イオンを含むメリライト型化合物では $\mathrm{T}(1)$ を 2 価陽イオン が， $\mathrm{T}(2)$ を 4 価陽イオンが占める秩序型の原子配置をとる。Gugiaite ${ }^{9)}$ で は $\mathrm{T}(1)$ を $\mathrm{Be}^{2+}$ イオンが, $\mathrm{T}(2)$ を $\mathrm{Si}^{4+}$ イオンが占め, $\mathrm{Be}-\mathrm{O}=1.654 \AA$ ， $\mathrm{Si}-\mathrm{O}=1.625 \AA$ であり，両者の間に大きな差はないが秩序配置をとると報告 されている。 $\mathrm{Sr}_{2} \mathrm{ZnGe}_{2} \mathrm{O}_{7}$ では $\mathrm{T}(1)-\mathrm{O}=1.953 \AA ̊ \AA ， \mathrm{~T}(2)-\mathrm{O}=1.748 \AA$ である から $\mathrm{T}(1)$ を $\mathrm{Zn}^{2+}$ イオンが, $\mathrm{T}(2)$ を $\mathrm{Ge}^{4+}$ イオンが占めることが明らかで ある。

$\mathrm{Sr}_{2} \mathrm{ZnGe}_{2} \mathrm{O}_{7}$ 構造中の $\mathrm{Ge}_{2} \mathrm{O}_{7}$ 双四面体では，両四面体を架橋する $\mathrm{O}(1)$ 原 子を含む $\mathrm{Ge}-\mathrm{O}$ (1) 距離が最も長い(Table 4 参照)。同様の傾向は 1 価また は 2 価の層間陽イオンを含むメリライト型構造に共通に認められる。しかし， 3 価の層間陽イオンを含むメリライト型構造では $\mathrm{T}(1) \mathrm{O}_{4}$ と $\mathrm{T}(2) \mathrm{O}_{4}$ 四面体 を架橋する $\mathrm{O}(3)$ 原子を含む $\mathrm{T}(2)-\mathrm{O}(3)$ 距離が最も長い。後者では $\mathrm{T}(2)$ を 2 価陽イオンが占めるので, 双四面体を形成する陽イオン間の反撥が小さ いのに対し，前者では $\mathrm{T}(2)$ を 3 価または 4 価の陽イオンが占めるために陽 イオン間反撥が大きくなり, $\mathrm{T}(2)-\mathrm{O}(1)$ 距離が長くなると推定される。

$\mathrm{Sr}_{2} \mathrm{ZnGe}_{2} \mathrm{O}_{7}$ の構造を層間に $\mathrm{Ca}^{2+}$ イオンを含むメリライト型構造と比較

Table 5 Comparison of average T-O and X-O distances $(\AA)$, tetrahedral angle variance $\left(\sigma^{2}\right)$ and lattice parameter ratio $(\mathrm{c} / \mathrm{a})$ in melilite type structures with divalent cations as $\mathrm{X}$.

\begin{tabular}{lcccccccc}
\hline & \multicolumn{3}{c}{$\mathrm{T}(1)$ site } & & \multicolumn{3}{c}{$\mathrm{T}(2)$ site } \\
\cline { 2 - 5 } \cline { 5 - 8 } & Atom & $\mathrm{T}(1)-\mathrm{O}$ & $\sigma^{2}$ & & Atom & $\mathrm{T}(2)-\mathrm{O}$ & $\sigma^{2}$ \\
$\mathrm{Ca}_{2} \mathrm{Al}_{2} \mathrm{SiO}_{7}$ & $\mathrm{Al}$ & 1.785 & 35.8 & & $\mathrm{Al}, \mathrm{Si}$ & 1.691 & 61.6 \\
$\mathrm{Ca}_{2} \mathrm{BeSi}_{2} \mathrm{O}_{7}$ & $\mathrm{Be}$ & 1.654 & 12.9 & & $\mathrm{Si}$ & 1.622 & 41.9 \\
$\mathrm{Ca}_{2} \mathrm{MgSi}_{2} \mathrm{O}_{7}$ & $\mathrm{Mg}$ & 1.915 & 5.5 & & $\mathrm{Si}$ & 1.619 & 47.1 \\
$\mathrm{Ca}_{2} \mathrm{ZnSi}_{2} \mathrm{O}_{7}$ & $\mathrm{Zn}$ & 1.937 & 4.7 & & $\mathrm{Si}$ & 1.617 & 66.3 \\
$\mathrm{Sr}_{2} \mathrm{ZnGe}_{2} \mathrm{O}_{7}$ & $\mathrm{Zn}$ & 1.953 & 3.5 & & $\mathrm{Ge}$ & 1.744 & 83.2 \\
& $\mathrm{X}-\mathrm{O}$ & $\mathrm{c} / \mathrm{a}$ & $\mathrm{T}(1)-\mathrm{O} / \mathrm{T}(2)-\mathrm{O}$ & $\mathrm{X}-\mathrm{O} / \mathrm{T}(2)-\mathrm{O}$ & Ref. \\
$\mathrm{Ca}_{2} \mathrm{Al}_{2} \mathrm{SiO}_{7}$ & 2.563 & .6590 & 1.056 & & 1.617 & 7 \\
$\mathrm{Ca}_{2} \mathrm{BeSi}_{2} \mathrm{O}_{7}$ & 2.521 & .6723 & 1.020 & & 1.554 & 9 \\
$\mathrm{Ca}_{2} \mathrm{MgSi}_{2} \mathrm{O}_{7}$ & 2.576 & .6394 & 1.183 & & 1.591 & 8 \\
$\mathrm{Ca}_{2} \mathrm{ZnSi}_{2} \mathrm{O}_{7}$ & 2.569 & .6405 & 1.198 & & 1.589 & & 5 \\
$\mathrm{Sr}_{2} \mathrm{ZnGe}_{2} \mathrm{O}_{7}$ & 2.700 & .6533 & 1.120 & & 1.548 & this study \\
\hline
\end{tabular}




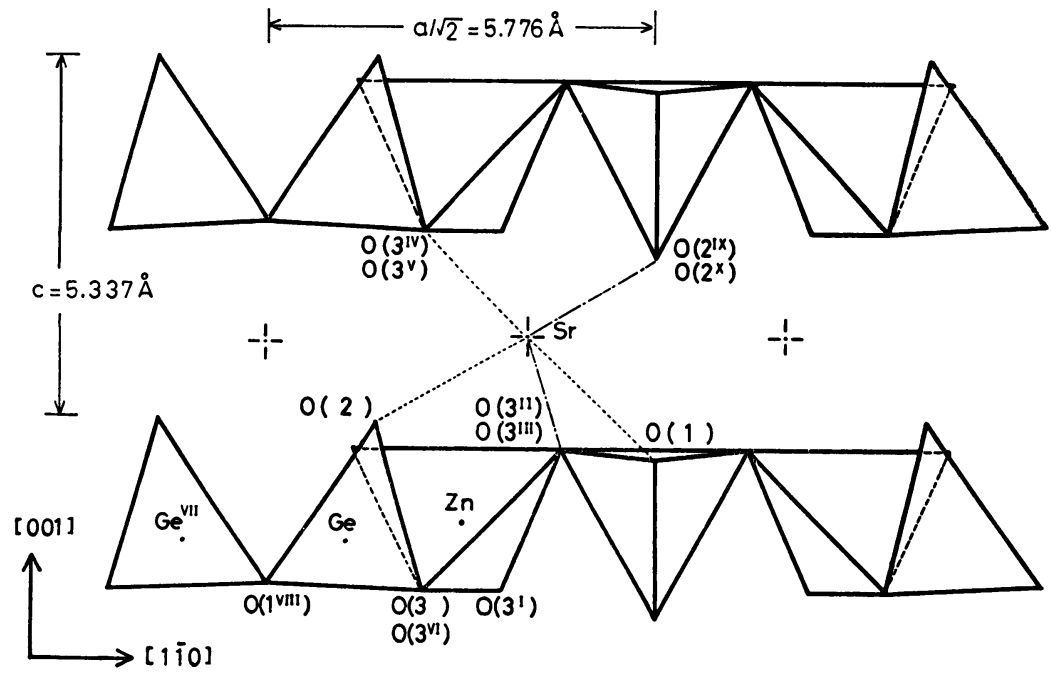

Figure 1 The structure of $\mathrm{Sr}_{2} \mathrm{ZnGe}_{2} \mathrm{O}_{7}$ projected along[110]. Notations are listed in :Table 4. Relatively shorter and longer $\mathrm{Sr}-\mathrm{O}$ bonds are represented by dotted and dashed lines respectively.

するために, 四面体の大きさ, 四面体角の分散 $\left(\sigma^{2}\right)^{16)}$, 軸率 $(\mathrm{c} / \mathrm{a})$ を求め, Table 5 に示した。 $\mathrm{Sr}_{2} \mathrm{ZnGe}_{2} \mathrm{O}_{7}$ の $\mathrm{T}(1)-\mathrm{O}$ は $\mathrm{T}(2)-\mathrm{O} よ り$ 長く, $\mathrm{T}(1) \mathrm{O}_{4}$ 四面体は $\mathrm{T}(2) \mathrm{O}_{4}$ 四面体よりも歪が小さい。これは $\mathrm{Ca}^{2+}$ イオンを含むメリ ライト型構造にみられる特徵と同じである。

$\mathrm{Sr}_{2} \mathrm{ZnGe}_{2} \mathrm{O}_{7}$ 構造の (110) 投影図を Fig. 1 に示す。メリライト型構造中の 四面体層は，理想的には 4 回回反軸を $\mathrm{c}$ 軸に平行にもつ $\mathrm{T}(1) \mathrm{O}_{4}$ 正四面体と， 3 回回転軸を $\mathrm{c}$ 軸に平行にもつ $\mathrm{T}(2) \mathrm{O}_{4}$ 正四面体が頂点を共有して結合した ものとして表わされる。酸素原子は $\mathrm{c}$ 軸に垂直な層をなして配列しているが， 同一層内の酸素原子が完全に $\mathrm{c}$ 軸に垂直な同一平面上にある場合には $\mathrm{T}(1)$ $\mathrm{O} / \mathrm{T}(2)-\mathrm{O}$ は 1.155 となる。Shi and $\mathrm{Yeh}^{17)}$ はメリライト型化合物の格子 定数を比較し， T (1) イオンの種類だけが異なる化合物の間では $\mathrm{a}$ 軸の長さ はイオン半径に従って変化するが $\mathrm{c}$ 軸の長さはほぼ一定であることを見い出 した。 $\mathrm{T}(2) \mathrm{O}_{4}$ 四面体の高さが $\mathrm{T}(1) \mathrm{O}_{4}$ 四面体の 厚さ（4 回回反軸に垂直な, 酸素原子を含む平面間の距離）よりも大きいために $\mathrm{T}(1) \mathrm{O}_{4}$ 四面体の大きさ 


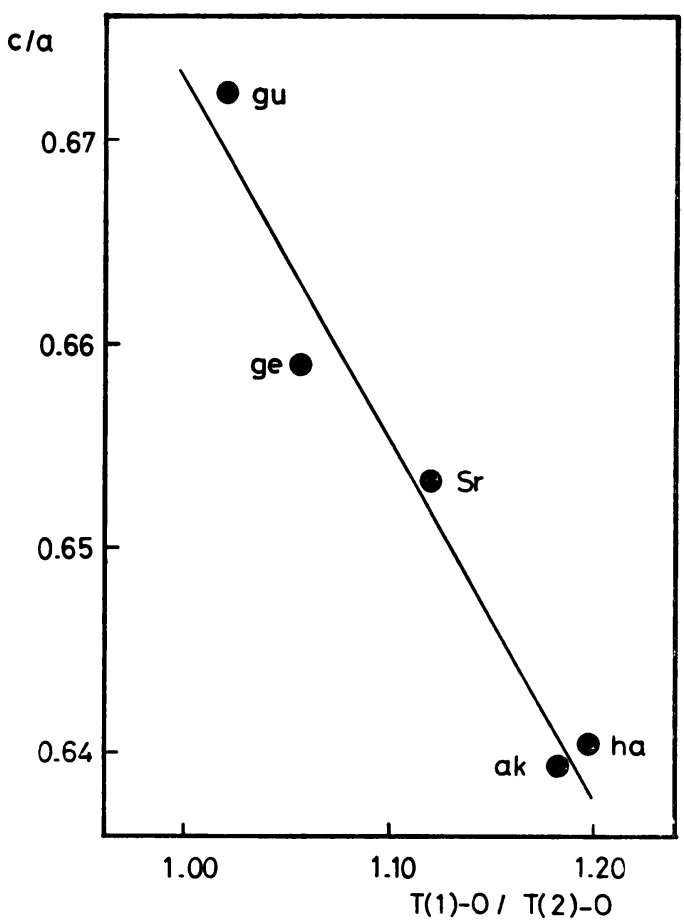

Figure 2 Plots of lattice parameter ratio(c/a) vs $\mathrm{T}(1)-\mathrm{O} / \mathrm{T}(2)-\mathrm{O}$ in melilite type structures with divalent cations at interlayer sites. $\mathrm{Sr}$, gu, ge, ak and ha represent $\mathrm{Sr}_{2} \mathrm{ZnGe}_{2} \mathrm{O}_{7}$, gugiaite $\left(\mathrm{Ca}_{2} \mathrm{BeSi}_{2} \mathrm{O}_{7}\right)$, gehlenite $\left(\mathrm{Ca}_{2} \mathrm{Al}_{2} \mathrm{SiO}_{7}\right)$, åkermanite $\left(\mathrm{Ca}_{2} \mathrm{MgSi}_{2}\right.$ $\left.\mathrm{O}_{7}\right)$ and hardystonite $\left(\mathrm{Ca}_{2} \mathrm{ZnSi}_{2} \mathrm{O}_{7}\right)$, respectively.

は $\mathrm{c}$ 軸の長さにそれ程影響を与えないと彼らは説明している。実際の構造解 析結果によれば， $\mathrm{T}(2) \mathrm{O}_{4}$ 四面体に比較して $\mathrm{T}(1) \mathrm{O}_{4}$ 四面体が相対的に大き い, 即ち $\mathrm{T}(1)-\mathrm{O} / \mathrm{T}(2)-\mathrm{O}>1.155$, hardystonite の構造においても $\mathrm{T}(1) \mathrm{O}_{4}$ 四面体の厚さよりも $\mathrm{T}(2) \mathrm{O}_{4}$ 四面体の高さの方が大きくなるように歪んで おり， $\mathrm{T}(1) \mathrm{O}_{4}$ 四面体の大きさが $\mathrm{c}$ 軸の長さに大きな影響を与えないとする 彼らの考えを支持している。また，Kimata and Ohashi ${ }^{9)}$ は $\mathrm{Ca}^{2+}$ イオンを 含むメリライト型硅酸塩について， $\mathrm{T}(1)-\mathrm{O}$ 距離が長くなるに従って c/a の 值が減少することを報告しているが，これは $\mathrm{c}$ 軸の長さが一定と考えれば 
Shi and Yeh の指摘と同様な結晶化学的傾向である。

層間に 2 価陽イオンを含むメリライト型化合物の $\mathrm{T}(1) \mathrm{O}_{4}$ 四面体, $\mathrm{T}(2) \mathrm{O}_{4}$ 四面体, $\mathrm{XO}_{8}$ 多面体の大きさが変化した際の軸率の変化を検討した。 $\mathrm{c} / \mathrm{a}$ と $\mathrm{X}-\mathrm{O} / \mathrm{T}(2)-\mathrm{O}$ の間には顕著な相関は認められなかった。しかし, Fig. 2 に 示すように $\mathrm{c} / \mathrm{a}$ と $\mathrm{T}(1)-\mathrm{O} / \mathrm{T}(2)-\mathrm{O}$ の間に直線関係が認められた。この関 係は $\mathrm{T}(2) \mathrm{O}_{4}$ 四面体が相対的に大きくなると $\mathrm{c}$ 軸を長くする効果が大きいこ とを示している。Fig. 1 の $\mathrm{SrO}_{8}$ 多面体において, 点線で示した $\mathrm{Sr}-\mathrm{O}(2)$, $\mathrm{Sr}-\mathrm{O}\left(3^{\mathrm{iv}}\right), \mathrm{Sr}-\mathrm{O}\left(3^{\mathrm{v}}\right), \mathrm{Sr}-\mathrm{O}(1)$ の原子間距離は平均より短かい。 $\mathrm{T}(2) \mathrm{O}_{4}$ 四 面体が大きくなると $\mathrm{O}(2)$ 原子は層状の酸素原子面から突出し, $\mathrm{Sr}-\mathrm{O}(2)$ 距 離が著しく短かくなる。これを補償するためには層間の Sr-Sr 距離を短かく するか，または層間隔を大きくするかであるが，実際の構造は後者によって 安定化されていると推定できる。

\section{謝辞}

本研究を行なうに際し, 有益な御助言を頂いた筑波大学木股三善博士に感 謝の意を表します。

\section{文献}

1) "Powder Diffraction File" published by JCPDS International Centre for Diffraction Data, Pennsylvania, (1981)

2) Deer, W. A., Howie, R. A. and Zussman, J.: "Rock Forming Minerals", vol. 1, Longmans, London, pp. 236-255, (1962)

3) Smith, J. V.: Amer. Miner., 38, 643-661 (1953)

4) Bartram, S. F.: Acta Cryst., B 25, 791-795 (1969)

5) Louisnathan, S. J.: Z. Krist., 130, 427-437 (1969)

6) Louisnathan, S. J. : Z. Krist., 131, 314-321 (1970)

7) Louisnathan, S. J. : Canad. Miner., 10, 822-837 (1971)

8) Kimata, M. and Ii, N.: N. Jb. Miner., Mh., 1-10 (1981)

9) Kimata, M. and Ohashi, H.: N. Jb. Miner., Abh., 143, 210-222 (1982)

10) Rietveld, H. M.: J. Appl. Cryst., 2, 65-71 (1969)

11）越智康雄・森川日出貴・丸茂文幸・野崎浩司 : 筧協誌, 91, 229-235 (1983)

12) Bond, W. L.: Rev. Sci. Instr., 22, 344-345 (1951).

13）田中清明・丸茂文幸：結晶内電荷分布解析プログラム, 伊藤徹三編, 文部省科 学研究費総合研究 B 56307002, 5-6 (1982) 
14) "International Tables for X-ray Crystallography", vol. 4, (Ed) Ibers, J. A. and Hamilton, W. C., Kynoch Press, Birmingham, pp. 148-175, (1974)

15）桜井敏雄編：結晶解析ユニバーサルプログラムシステム(1), 日本結晶学会, (1967)

16) Robinson, K., Gibbs, G. V. and Ribbe, P. H. : Science, 172, 567-570 (1971)

17) Shi, Y. Q. and Yeh, D.N.: Ko shueh Tung pao, 23, 623-626 (1978) 